\title{
Feminist institutionalism and women's political leadership in devolution era Scotland
}

\author{
Jenny Morrison ${ }^{1} \cdot$ Ewan Gibbs $^{1}$
}

Accepted: 5 November 2021

(c) The Author(s), under exclusive licence to Springer Nature Limited 2021

\begin{abstract}
Scotland is a leading example of the international institutional turn in feminism since the late twentieth century. Feminist activists played a leading role in shaping a new Scottish Parliament in the 1980s and 1990s, which has influenced the politics of devolution since 1999. This article appraises this experience using a combination of feminist texts drawn from across the time period as well as autobiographies and biographies of prominent Scottish female politicians. The findings demonstrate that Scottish feminine political leadership has been strongly moulded by a rejection of Westminster's archaic and conflictual politics, which are understood to be masculine. Feminists' experiences of organising in the Women's Liberation Movement pointed to the importance of institution building and pragmatically working towards shared goals across traditional divisions. Scottish feminists' emphasis on consensus decision making and achieving objectives across party lines, especially on subjects gender-coded as women's issues, has moulded a centre-left framing for Scottish women's leadership that rejects both conservatism and left-wing radicalism. The achievement of aspirations surrounding increased women's representation and leadership has perhaps come at the cost of the larger earlier ambitions for a more inclusive parliament accountable to the Women's Liberation Movement and working-class communities. These findings suggest that there are inherent limitations to institution building feminism based on elite networks.
\end{abstract}

Keywords Scotland · Gender · Devolution · Feminism · Representation · Leadership

In the summer of 2017, Scotland's First Minister, Nicola Sturgeon, caused a minor stir at an Edinburgh Book Festival discussion when she declared that she regretted the naming of the Scottish National Party (SNP). Sturgeon explained that "what

Jenny Morrison

Jennifer.Morrison@glasgow.ac.uk

Ewan Gibbs

ewan.gibbs@glasgow.ac.uk

1 University of Glasgow, Glasgow G12 8RT, UK

Published online: 21 November 2021 
those of us who do support Scottish independence are all about could not be further removed from some of what you would recognise as nationalism in other parts of the world' (BBC News 2017). Within an international context where nationalism was associated with the reactionary machismo of Trump, Putin and Erdogan, and a UK one of Brexit, it seemed fundamentally out of vogue with the form of tolerant and progressive politics that Sturgeon champions. Five years earlier, Sturgeon has been willing to wear the label of nationalist, but only to refute the 'existentialist' variety of Scottish nationalism that locates the justice of its cause in bygone days. Instead, she was motivated by a 'utilitarian' appeal to nationhood based on using constitutional change to best realise social justice (Torrance 2013). During COVID19 , Sturgeon's personal authority was bolstered by daily personal briefings that conveyed an intimacy and social and cultural familiarity with the Scottish public. In this respect, she can be seen to parallel other female leaders such as Germany's Angela Merkel or New Zealand's Jacinda Arden (Read 2020).

This article assesses the efficacy of institutional feminist practice in the late twentieth and early twenty-first century by exploring the gendered dimensions of female Scottish political leadership. We argue that the rising prominence of women in Scottish politics is the outcome of decades of feminist activism which has consciously sought to remould Scottish politics by shaping the architecture of devolution. These shifts can be traced through the development of second-wave feminism in the 1970s and 1980s through to the making of the Scottish Parliament that finally took form in 1999, and then in Holyrood's first two decades. As is demonstrated by the figures referred to above, Sturgeon is just one of a number of prominent female political figures to emerge within liberal democracies during the twenty-first century who are associated with growing women's political representation, opposition to populism and a pragmatic commitment to democratic norms (Thiec 2010; Read 2020). Scotland's case can be understood to be emblematic of an international trend towards embedding certain feminist values and practices within parliamentary politics.

Gibbs and Scothorne (2020) addressed the failure of varieties of 'masculine populism' that animated defensive workplace and community mobilisations between the 1960s and 1990s. They demonstrated that a politics based around appeals to gendered forms of authentic leadership which juxtaposed justice with legality and private property lost its power as devolution dawned. This was an outcome of the realisation of an alternative legitimate national authority in Scotland which was less easily discounted than the UK government. These trends were confirmed at the 2021 Scottish Parliament election when Alex Salmond's Alba Party, which represented a more aggressive masculine form of politics centred on a nationalist 'fundamentalism' that was dismissive towards the devolved parliament, only achieved $1.7 \%$ of the popular vote. Sturgeon's SNP embodied a more 'gradualist' variety of nationalism committed to a form of independence which consciously builds on the achievements of devolution topped the poll with over 40 per cent of the vote (BBC News 2021a, b, c; Lynch 2013).

This article is based on an original document analysis of texts written by feminist activists, academics and politicians throughout the campaign for devolution and during the opening decades of the Scottish Parliament. The experiences and perspectives of feminists involved is crucial to understand the development of feminist 
institutional practice. Document analysis delivers insight into participants' perspectives from the time, without the intrusion of dominant national memories that have been built around the Scottish Parliament (McGarvey and Cairney 2008). The documents also incorporate the voices of feminist activists who have since died. We draw on key contemporary feminist writings including A Woman's Claim of Right (1991), the document written in response to the male-dominated Scottish Constitutional Convention and which formed the basis of much women's devolution campaigning, two anthologies Grit and Diamonds (1990), edited by Shirley Henderson and Alison McKay and Women and Contemporary Scottish Politics (2001), edited by Esther Breitenbach and Fiona Mackay as well as a range of contemporary feminist articles exploring the impact of feminist campaigning on the institutions of devolution. Taken together, these documents represent key high-profile feminist texts of the devolution period. We supplement these texts with an analysis of the autobiographies of Winnie Ewing (2004), the first female SNP MP, and Maria Fyfe (2014) former Labour MP for Maryhill and leading advocate of devolution. Our thematic analysis of the documents produced themes relating to the following: (1) Criticisms of Westminster parliamentary culture, (2) Women's experience of extra-parliamentary activism, (3) Coalition building between activists, and (4) Feminist institution building. These themes fed into our assessments of the impetus behind the Scottish feminist institutional turn, its objectives and how it has shaped the politics of devolution. The following section outlines the framework for understanding the international feminist institutionalist turn from the 1980s, and Scotland's place in this turn, in order to situate the discussion in sections three and four. Section three outlines the development of an archetypal female Scottish politician and the contribution of feminists to designing Holyrood. The final section moves on to the period of devolution, demonstrating women politicians' tendency to progress through established routes from the third sector organisations, gendered employment patterns in social policy roles and campaigning issues to Holyrood. Sturgeon's championing of causes gender-coded as women's concerns is also assessed. These findings support Shaw's (2020) conclusions that the 'founder members' status enjoyed by female members of the Scottish Parliament has contributed to a distinctive political culture, but they question the success of institutional feminism in achieving more substantive egalitarian objectives.

\section{Feminist institution building}

Scottish feminists were part of an international trends towards institution building during the closing decades of the twentieth century and into the new millennium. European Union expansion and the building of new democracies in Central and Eastern Europe provided an important context for the discussion of nation building centred on the overlap between the state, parliaments and civil society. Feminist political science perspectives underline the relationship between feminist activist movements and female elected members in attempting to shape the norms of parliamentary institutions. The 'institutional turn' is grounded in questioning 'how do institutions affect the daily lives of women and men, respectively?' (Krook and 
Mackay 2011). In a narrower British context, devolution was seen as an opportunity for feminists to achieve significant changes in the environment of a new experiment in national democracy at a Scottish, Welsh and Northern Irish level. The new assemblies held out the hope of a 'blank canvas' (Shaw 2020) for democratic innovation, but in practice were subject to both the normative assumptions conditioned by centuries of Westminster politics and the aspirations of feminist activists which were specifically formulated in opposition to these expectations.

Women were historically overlooked, or even denigrated, as political participants in twentieth century Scotland. The civic nationalist agenda that emerged during the 1980s, and that was then consolidated during the 1990s, was highly influenced by feminists and offered hopes for change. Late-twentieth century second-wave feminism provided important inheritances when it came to concern over women's representation in the new Scottish Parliament which was founded in 1999. Women activists mobilised to shape a parliament imbued with the 'feminine' values of consensus, representation and participation (Breitenbach and MacKay 2001).

Yet, devolution era politics also eschewed much of the radical aims previously associated with feminist activism. Since the late 1990s, Scotland has continued to shift towards an increasingly feminised but low-paid service economy (Law and Mooney 2010). Wendy Alexander's role in the Scottish Executive exemplified these developments. Alexander oversaw the repeal of section 28 as a minister in the first devolved Scottish administration, which was a key battle that established the socially liberal character of Scotland's new polity. Despite perceptions of a likely conservative backlash, the repeal of homophobic legislation was successful and paved the way for future tolerant reforms (Hassan 2019). However, as Enterprise minister, Alexander also put forward the Smart, Successful Scotland (Scottish Executive 2001) strategy based on embracing economic liberalisation. Older regional policy approaches based on greenfield investment were abandoned in the context of the microelectronics crisis. Female workers were disproportionately affected by electronics plants closures which further encouraged working-class women into lowpaid service sector employment (Turok 2007). Social and economic liberalisation were not entirely synchronous nor necessarily caused by the same societal processes. Yet, under devolution they have jointly been administered by New Labour and then SNP administrations who have viewed these as at least compatible, and often mutually desirable, objectives.

There is a long history of women's activism on the Scottish left, but the maledominated political sphere tended to render women as supporting rather than central figures (Hughes 2010). Women's negative experiences were a significant factor in the politics of the Women's Liberation Movement (WLM) of the 1970s (Browne 2014) and activists advocated horizontalism, consensus building, and participation against supposedly masculine adversarial hierarchical organisation. The WLM was initially sceptical of existing parliamentary and state institutions and developed parallel women's institutions such as Women's Aid or Rape Crisis. Initially, the suspicion of patriarchal institutions combined with a perception that Scotland harboured a particularly sharp form of misogyny to mean Scottish feminism tended not to engage with campaigns for devolution. Browne (2014) notes that the Scottish Women's Liberation Journal reported Donald Dewar, then Labour Party candidate for the 
1978 Garscadden by-election and future Scottish Labour Party leader and First Minister, opposed abortion law reform while the Scottish Council of the Labour Party's subcommittee on abortion recommended adopting a 'low profile' on the issue. The contrast between the Labour Party's support for abortion rights in England and vacillations in Scotland meant the WLM harboured concerns about a Scottish Assembly even in the hands of the left.

However, the rise of Thatcherism, the defeats suffered by the British left and concordant threats to women's liberation encouraged a shift in women's organising which culminated with feminist involvement in creating the architecture of devolution. During the 1980s, feminism across the Global North is often held to have undergone an 'institutional turn' where feminists worked within the structures of the state to challenge the formal and informal 'rules of the game' which create bias against women (Krook and Mackay 2011). Scotland provided opportune territory for an institutionalist feminist turn. The international crisis of the left had a distinctive national character in the context of increasingly pronounced national dynamics. A cross-party and cross-class 'Civic Scotland' coalition emerged around devolution. It was stimulated by the combination of intensifying deindustrialisation, trade union defeats, and Scotland's growing political differentiation from England (Stewart 2009). Unlike during the 1970s devolution debates, feminists who had increasingly joined political parties and built enduring organisations were more able and inclined to shape the emerging Scottish parliament (Breitenbach 1991). Feminist activists in the Scottish Abortion Campaign had become allies of the Scottish Trades Union Congress (STUC) and overlapped with the STUC Women's Committee (Hay 2020). In the early 1970s, the STUC had put forward an agenda for devolution centred on a 'workers' parliament' (Phillips 2019). By the late 1980s, it was at the head of a more pluralist and elitist devolution coalition in a period where the (usually male) industrial worker no longer provided a singular subject for historical change (Aitken 1997).

A Scottish parliament was conceived as the embodiment of progressive national values. Yet, the Scottish Constitutional Convention (SCC) emerged as an elite alliance of cross-party, trade union, and local government forces that was largely removed from popular mobilisations. Although the demand for devolution was certainly spurred on by objections to the Community Charge reform to local government taxation (the 'poll tax'), and a large high-profile non-payment campaign, the SCC found itself compromised on the issue as its local government and party representatives were legally and financially obliged to collect the tax (Gibbs 2016). There were some significant exceptions, such as the 1992 'March for Scottish Democracy' protest at the European Summit in Edinburgh where the author and public intellectual, William McIlvanney, proclaimed Scotland was an inclusive 'mongrel nation' (Ascherson 2003). Hames (2020) juxtaposes the 'dream' that animated high-profile literary advocates of devolution like McIlvanney with the 'grind' of Labour Party electoral politics and committee room bargaining that ultimately delivered a Scottish parliament.

The devolution campaign advocated a 'new politics' based on consensus, powersharing, and participation. These values, drawn from the WLM, were driven by feminist activists who argued for it within the devolution movement. In A Woman's 
Claim of Right (1991), Scottish feminists contended that if women did not fight for equality, then the new Scottish parliament would replicate the exclusions found at Westminster (Galloway and Robertson 1991). The authors of A Women's Claim of Right can be seen as elite activists working to achieve changes to political culture that would take a Scottish parliament towards more 'participatory' politics (Galloway and Robertson 1991, p. 4). Notably, A Woman's Claim of Right, and the wider devolution campaign, framed British political culture as uniquely conflict-based and masculine, which contrasts with the earlier fear in the Scottish WLM that Scotland harboured a particularly misogynistic culture. Macmillan (2020) emphasises that the Westminster system was a 'negative template' against which the institutions of Scottish devolution were designed. Campaigners appealed to 'Europe', particularly Scandinavia, for its perceived consensual politics and high levels of women's representation (Roddick 1991). These connections demonstrate that Scottish feminists were part of an international discussion and that their institutional turn was consciously devised and understood in a comparative context.

While all institutions are constrained by broader cultural contexts, Mackay (2011) explains that new institutions have a 'permissive stage' that can allow for the embedding of gender equality. Devolution campaigning embodied the culture and politics its participants promoted for the new parliament. Alongside consensus and participation, women's campaigning coalesced around a push for equal gender representation in the Scottish Parliament (Breitenbach and MacKay 2001). As with A Woman's Claim of Right, the 50:50 campaign aimed to build consensus among women across all the political parties which culminated in the 'gender coup' of the 1999 elections which saw a record 37.2 per cent women among the MPs of the first Scottish parliament (Breitenbach and MacKay 2001). Yet, this success also illustrates the limitations of such activism: it encouraged the professionalisation of formerly grassroots women's organisations that eroded their accountability to a broader movement. Professionalisation reframed participatory politics as elite women's third sector 'expert' input into government decisions rather than the more democratic, if messier, understanding of the term as incorporating public debate through movements and communities. Moreover, the campaign perhaps contributed to the acceleration of Labour's turn towards professional middle-class representation and certainly did little to confront it (Keating and Cairney 2006). We argue this model informed women's campaigning and the emerging generation of feminine leadership in devolved Scotland with its focus on policy reform which could win cross-party support, 'participation' understood as allowing elite women's institutional representation and a form of gender representation that selectively draws on feminist history but broadly abjures the more radical implications of feminist politics.

\section{The foundations of a feminist vision for devolution}

The foundations of a distinctive form of feminine political leadership in late twentieth century Scotland lie in women parliamentarians' responses to sexist behaviour from their male colleagues. These cross-party experiences laid the foundations for the forging of an agenda centred on building a Scottish parliament that was 
explicitly orientated towards improving women's political representation and fostering a more inclusive political culture. A Woman's Claim of Right highlights sexist attitudes towards women and a regressive parliamentary culture as core aspects of women's exclusion from formal politics. In their memoirs, Winnie Ewing and Maria Fyfe both detail the sexism they faced from other MPs, including during their maiden speeches. Ewing recollected a heckler shouting, 'just give her a kiss' (2004) and being 'interrupted whenever I spoke, I was regularly insulted, and I was even defamed once or twice'. Fyfe's experience indicates that these behaviours were not reserved for MPs representing minor parties. During her maiden speech, Fyfe attacked the Thatcher government's treatment of the unemployed. In her view, the heckling that she received from the Tory benches was 'fair enough' and part of the parliamentary game. She contrasted this with 'the kind of boorish behaviour that would draw a reprimand from any schoolteacher in the classroom but went unremarked by the Speaker or his deputies until it got out of hand' that she was also subjected to, unlike her male colleagues (Fyfe 2014).

These personal experiences fed a wider revulsion towards the archaic political culture of Westminster, which is masculine, combative, and eludes a form of farcical aristocratic class privilege. Commenting on the very architecture of the Commons, which dictates that two sides sit opposing each other kept the length of two swords apart, Fyfe (2014, p. 351) wrote that 'some love this kind of tradition. I find it merely irritating'. There were also ribbons for members to hang up their sabres upon arrival at parliament, but no wastepaper bins. Fyfe also condemned the place alcohol played in parliamentary life, feeling appalled by the sight of MPs and Lords swiftly vacating Westminster's bars and restaurants for votes after sitting out debates. Ewing (2004) recalled a letter she sent to the Scotsman in 1968 that attacked MPs for the amount of time they spent at bars was bitterly resented by Scottish Labour MPs. In response, Willie Hannan, a temperance advocate and Labour MP for Maryhill, had put forward a motion of censure that he had to be convinced to remove.

Those episodes spoke to a broader malaise in the context of male-dominated political structures. Marie Kane (1990), who was appointed Scotland's first women's officer by Stirling District Council in 1985, recollected five years later that at the time she was appointed, almost nine in ten of Scotland's Regional Councillors were male as were the overwhelming majority of senior council officers. This was reflected in the priorities of Scottish local government: the needs of men's football teams were prioritised over largely women carers. Kane's achievements (1990) included increasing the women's budget from $£ 10,000$ to $£ 450,000$ and developing a Shoppers' Creche, bus services, a Women's Technology Centre, a Women's Unit within the council as well as devising a Women and Health Project. These practically focussed undertakings and the struggle Kane and her supporters fought within the structures of local government rather than between parties are emblematic of the 'campaigning politics' which the feminist Church of Scotland minster, Kath Galloway, and human rights activist, Judith Robertson (1991), diagnosed as anathema to 'adversarial, competitive and careerist party politics' in their contribution to the Women's Claim of Right. Another reflection on 1980s Scotland by the feminist activists, Jennifer B. Kerr and Paula Jennings (1990), underlined the optimism they felt about the role that Women's Aid and Rape Crisis played in fostering 
a 'woman-centred' politics. These developments were informed by a rejection of the Thatcher government's antiquated moralism, especially Sect. 28. In rejecting the message emanating from the government in London, Scottish feminists had also begun to fashion their own path, no longer being reliant on reading the 'best books' from London and instead partaking in a more genuinely solidaristic international movements. Kerr and Jennings (1990) underline the basis upon which the feminist movement moved towards a politics of devolution, both from the increasingly negative perceptions of British politics but also hopeful experiences of distinctive local and national institution building within Scotland.

Maria Fyfe's support for a devolved Scottish parliament was strengthened by her Westminster experiences. She was scathing about being given only a minute to speak during a debate on Cornton Vale, Scotland's sole women's prison, despite the fact she was one of only three Scottish women MPs. This instilled Fyfe's support for devolution, but also coloured her perspective on what a Scottish parliament should look like. It would need to be a body that 'started earlier in the day, and finished at a sensible time' (Fyfe 2014) to accommodate the requirements of women parliamentarians with family responsibilities and avoid continued domination by the 'overgrown schoolboys' who gathered at Westminster.

During 1994, Scotland's leading nationalist intellectual, Tom Nairn (1994), claimed that women's representation and concentration on social conditions women faced had become formative to the devolution movement. These concerns represented 'a small " $\mathrm{n}$ " nationalist banner-an emblem of the kind of country and the style of nationalism people really want'. Seven years earlier, a newly elected Fyfe had signed a letter published in Fortnight magazine along with Nairn and other signatories across party divides. The letter centred on agreement that Scotland exhibited 'a degree of consensus in collaboration impossible in England' (Purdie et al 1987). This hopeful vision rested on expectations of a 'united front' behind devolution on the basis of 'grassroots' activism (Ibid). These hopes were realised through the SCC, but with important constraints.

A Woman's Claim of Right (1991) sprang from the SCC's women's committee but nevertheless provided the Scottish Parliament with some important utopian aspirations. At the SCC's meeting in Glasgow during the summer of 1990, the women's committee were provided 'a guard of honour' by Wildcat Theatre actors dressed as rent strikers from 1915, symbolising the historical struggle of working-class women and continuity through to the women's movement of the 1980s and 1990s (Fyfe 2014). The same year, Henderson and Mackay (1990) published Grit and Diamonds, an anthology that celebrate ten years of women's movement activism in Scotland. It profiled second-wave feminism as pluralistic and porous. The entries encompassed striking miners' wives and factory occupiers alongside representatives of Women's Aid, Rape Crisis, and the Scottish Abortion Campaign. In the eyes of the authors, these groupings would form the basis for a more inclusive form of Scottish rather than British democracy.

Both Fyfe and Ewing's autobiographies also demonstrate that positive examples from other countries as well as the negative example of Westminster shaped their visions for a devolved Scottish polity. In Ewing's (2004) case, her experience as a member of the European Parliament between 1975 and 1999 was formative. Ewing 
found herself surrounded by representatives from other small nations in a parliament focussed on consensual rather than adversarial decision making. During her period as an MEP, Ewing was closely involved in securing European funding for Highland economic development and in getting District and Regional Councils a seat at the European table, to some extent bypassing reliance on UK government (McCullough 2018). Fyfe (2014) visited both the Gaza strip and Nicaragua on fraternal delegations. She was especially impressed by the Sandinista movement's inclusion of women in governing structures and their commitment to women's rights in a traditionally conservative country.

A strong influence on representation and comparison with other European nations is apparent in A Woman's Claim of Right (1991), which condemned 'Scotland's map of shame'. Unlike some of its Scandinavian neighbours that had women's political representation rates of approaching a third in national parliaments, under five per cent of Scottish MPs were women. Women were presented as inherently political through their household role, but not engaged in the partisan chest-beating of maledominated party politics (Robertson and Galloway 1991). The women's movement was positioned as continuing a long tradition of working-class community struggles for better conditions (Hersh 1991). Efforts to increase women's representation through equality agendas in parties choosing candidates for winnable seats were suggested as mechanisms for gender equality (McCrae 1991). A more ambitious focus was on determining the shape of the parliament to come. As Isobel Lindsay (1991), who had recently left the SNP over the party's failure to engage with the SCC, put it: 'the very fact that these women are often uncomfortable with the confrontational style and the personal ambition of much party politics is a very strong argument for trying to have them as members of a national legislature'. Her hope that it 'would become so familiar as to be regarded as ordinary' for women to be members of parliament has been realised under devolution.

By the early 1990s, Scotland's new parliament was being moulded and so was a form of feminine political leadership. This form of leadership evolved in response to the sexism and mistreatment women parliamentarians received at Westminster, and a broader criticism of patriarchal and archaic nature of the House of Commons. The feminist critique came to centre on the extent of women's representation but also the adversarial culture of British politics. These were further instilled by the sensibility of a past and present community tradition of women's activism on quotidian or 'everyday' concerns. Perhaps this was best summarised in 2018 by Maria Fyfe unveiling a statue to her hero, Mary Barbour, the leader of the 1915 rent strike. Fyfe was present as Chair of the Remember Mary Barbour Association at a cross-party ceremony. She was also joined by Glasgow's SNP Lord Provost, Eva Bolander (Dalziel 2018). In her autobiography, Fyfe (2014) noted Barbour did not receive the same plaudits as historic male labour movement leaders. As well as her leadership of the rent strike it was also her achievement in municipal services through the developments of children's play parks, washhouses, municipal baths, free milk, and family planning that Barbour ought to be remembered for. The ideological foundations of a distinctive Scottish feminine political leadership that grew to fruition under devolution lay in a self-styled practical form of feminism, focussed on answering the concerns of women through women's representation and rejecting the perceived 
overly partisan male politics of both the British establishment and radical left. While this politics occasionally found itself opposed to the constituencies and traditions it claimed to embody, it was nevertheless the main driver in transforming gender representation and moulding Scottish Parliamentary culture.

\section{Scottish politics under devolution}

The devolved Scottish Parliament was greeted with optimism by many feminists, as well as wider 'progressive' civil society. Mooney and Poole (2004) highlight that in the early days of devolution, Scotland was seen as a 'land of milk and honey' for social policy, reflecting long-standing assumptions about Scottish egalitarianism combined with the new parliament's reputation for openness and inclusion. As the youngest woman member of the first session of the devolved parliament and the future first female First Minister, Nicola Sturgeon embodies the feminisation of Scottish politics under devolution. Additionally, Sturgeon's reputation for supporting equalities reform and as a pragmatic and consensus-driven politician (Torrance 2015) is representative of the 'new politics' promoted during the campaign for devolution.

Mitchell (2010) referred to claims of a 'new politics' in commentary on the new parliament as 'narcissism of small differences' which failed to acknowledge the basic similarities between Holyrood and Westminster. He points out that the Parliament was Executive dominated from the start and that the four founding principles of the Scottish Parliament-sharing power, accountability, access and participation and equal opportunities — can be interpreted through a wide range of lenses. While initially there was a proposal not to introduce 'adversarial' First Minister's Questions (FMQs) in the line of Prime Minister's Questions, in 2000 FMQs were instituted as a form of accountability. FMQs remains a high-profile partisan confrontation in the political week. Sturgeon was a notable participant in the combative arena of FMQs from when they were first instituted, claiming to 'love' the debate (Kenny 2011). As feminist institutionalists argue, while institution building can offer some opportunity for embedding different values, no institution emerges completely new but rather they are shaped by the legacies of, and their interaction with, other existing institutions (Mackay 2011). Sturgeon's performance in this adversarial form of politics, antithetical to the supposedly consensual new politics of the Scottish Parliament, helped cement her status as an important political player. It is telling of continued gender contingencies in political leadership that Sturgeon suffered from the detriment of the 'nippy sweetie' label alongside wining the Herald newspaper's Debater of the Year award in 2004 (Higgins and Mackay 2016). Subsequently, the SNP undertook a sustained media effort to soften her image.

The principal area where there was a marked change from Westminster was, of course, in gender representation. While falling short of 50:50, the 'gender coup' of 37.2\% women MSPs elected in 1999 was a remarkable increase in women's representation in Scotland, and Scottish Parliament was held to 'set the standard' for gender representation in the UK (Kenny 2011). Westminster is increasingly meeting this standard: $33.8 \%$ of MPs are women and $40 \%$ of Conservative MPs, not traditionally 
thought of as a party of equality, are currently women (Commons Library 2020). Feminists have highlighted that the presence of high-profile female figures in parliament can distract from the far lower levels of women's representation at, for example, the local council level (Kenny 2011). Additionally, equal representation has always been partial with, for example, no women of colour elected to the Scottish parliament before May 2021 (BBC 2021b). Nonetheless, the sense of being 'better' at gender representation, and the influence on promoting equal representation elsewhere in the UK, remains a powerful part of the devolution narrative in Scotland.

Alongside progress towards equal representation, devolved Scotland has also seen an increase in visible female leadership. Most high profile, of course, is Sturgeon herself whose first Cabinet had a 'headline-grabbing 50/50 gender split' (Torrance 2015) and who appointed Liz Lloyd as her chief of staff. Scotland's other two main parties, the Scottish Labour Party, under Wendy Alexander, Johann Lamont and Kezia Dugdale, and the Scottish Conservative Party, with Annabel Goldie and Ruth Davidson, have also had periods of female leadership. The period following the Scottish independence referendum saw the zenith of female leadership when all three main parties were led by women. Currently, the leadership of both the Labour Party and Conservative Party in Scotland sits with men-reminding us, perhaps, not to be complacent on equality. Nevertheless, female leadership can be said to be a, if somewhat unstable and changeable, feature of the devolved Scottish political landscape. Meanwhile, the cross-party promotion of women's representation has been a key feature of female leaders' political narratives. Sturgeon is on record as supporting 50:50 from the early 1990s, at odds with official SNP policy of the time, as well as emphasising the importance of having female role models in positions of power (Torrance 2015). Similarly, female Scottish Labour leaders from Wendy Alexander to Johann Lamont through to Kezia Dugdale have supported quotas for equal representation in politics and promoted greater representation of women in positions of power across public life.

While there has been increasingly visible female leadership in devolved Scotland, the practice of leadership and assessment of leaders remains firmly gendered, no more noticeably than in the constant comparison between Alex Salmond and Nicola Sturgeon. Sturgeon has long complained of sexism in the way women politician's dress and presentation are discussed in the media (Torrance 2015) but both the positive and negative comparisons of Sturgeon and Salmond display gendered understandings of leadership. As First Minister, Sturgeon commented that the early pejorative image of her as a 'nippy sweetie' resulted from her adoption of the adversarial and aggressive style of the male-dominated political world in which she found herself (Scotsman 2017). Yet, Salmond's notably confrontational style came alongside the perception he has a 'man-of-the-people bonhomie' (Torrance 2015). The intentional softening of Sturgeon's public image involved presenting her as more feminine, with Torrance (2015) also commenting on her cultivated empathy and rapport with children and families (Higgins and McKay 2016). Meanwhile, Sturgeon herself has made a point of stating she pursues a consensual political style focussing on unity rather than division (Torrance 2015). Sturgeon's consensus-building approach is also linked to the framing of her as a pragmatic, efficient decision-maker, a depiction Torrance (2015) notes is also applied to other female leaders with German 
newspaper Die Welt viewing Teresa May, Angela Merkel, and Sturgeon as 'clearing up the mess caused by men across Europe'.

The feminine roles assigned to political leaders such as Sturgeon is also indicative of their backgrounds, which shapes these media personas. Female MSPs from both Labour and the SNP, the two parties which in turn dominated the first two decades of the Scottish parliament, tend to have a shared background in 'feminine' jobs and organisations. Johann Lamont and Elaine Smith who served as Labour MSPs from 1999 to 2021 both have a background in teaching, Kay Ullrich, a key mentor for Sturgeon, was a social worker, Jeane Freeman trained as a nurse, while Jackie Baillie and Margaret Curran worked in council and community work. Law was another notable pathway, yet while legal professions may appear a common area of study and work for politicians in the UK, it is notable that key figures such as Roseanna Cunningham worked as a local council solicitor while Sturgeon famously worked as a third sector solicitor with Drumchapel Law Centre-both highly feminised areas of law which relate to social policy concerns and social inequalities. This shared background reflects the gendered reality of employment in Scotland but also likely shaped the orientation of female MSPs on social policy and childcare reform.

Moreover, a more directly feminist influence shaped some of the policy focus of MSPs, with a number of Labour Party parliamentarians sharing a background in feminist organisations which had also played a role in devolution campaigning. Several female Labour MSPs in the first session of the Scottish Parliament had backgrounds in the women's refuge movement in Scotland and were key to maintaining domestic abuse as a key priority for the government (Charles and Mackay 2013). Notable among these women was Johann Lamont, future Scottish Labour leader. While SNP MSPs were less directly connected to the WLM, given the WLM had traditionally fed into the trade unions and Labour, the legacies of the movement can be seen across the political spectrum where many high-profile female SNP parliamentarians have emphasised their feminism and support for feminist causes such as Joan McAlpine or Mhairi Black. Yet, it is notable that this rise in parliamentarians from the women's movement came alongside the professionalisation of WLM organisations and the establishment of new feminist bodies as third sector institutions. Some feminists have argued feminist groups have had to rely more on traditional lobbying than a participatory or partnership relationship with the Scottish Parliament (Breitenbach 2006).

Unsurprisingly, given the background of key women MSPs across the devolved parliament, and the feminist involvement in its establishment, key areas of policy reform emerged on equalities-related issues. Alongside repealing section 28, domestic violence and expanding early years of childcare were central policy areas of the first session of the parliament. Feminist scholars have stressed the importance of networks of feminist parliamentarians, some of whom were involved in the refuge movement, and the partnership process where Women's Aid helped draw up the initial National Strategy to tackle domestic violence with the Scottish parliament (Charles and Mackay 2013). While the first two sessions of the parliament were Labour/Lib Dem coalitions, since then, the SNP, and particularly Sturgeon, have similarly worked with the feminist third sector and held up childcare and welfare as important areas of policy, symbolised by the Baby Box (Scottish Government, nd1) 
and named person policies (Scottish Government, nd2). Other campaigns for which Sturgeon has voiced support-for example, equal marriage, ending period poverty and Time for Inclusive Education (TIE) campaign for LGBT education, a campaign which represents the logical extension of the earliest equalities gain of the Scottish Parliament in the repeal of section 28-exemplify the cross-party consensusbuilding approach to equalities campaigning. Yet, while, as with all campaigns, all named cases faced opposition, the key line of division was not party politics. On the contrary the campaigns gained widespread support across the SNP-Labour divide, and often wider cross-party backing, offering relatively easy victories in areas that already have substantial public support.

In spite of the general consensus in devolved Scotland regarding support for certain forms of equalities policies, episodes where grassroots women have organised to challenge power demonstrate the limitations of consensus politics. The 2004 Scottish nursery nurse's strike was a key moment. It was the largest all-out strike in Scotland since the 1984-1985 miner's strike (Mooney and McCafferty 2005). Childcare had taken on a special significance for the New Labour government at the UK level, as well as in Scotland, with employment, and therefore childcare to allow parents, mostly women, to work, positioned as the route out of poverty. The dispute emerged from the twin pressures of growing expectations of nursery nurses, who are also predominantly women, alongside low pay and conditions out of line with their key role as early years of educators (Mooney and McCafferty 2005). Nursery nurses, therefore, embodied the contradiction of policy which argued people should work their way out of poverty, while not challenging poverty wages and poor conditions, and offered a public face to the growing feminisation of poverty. Support for the strike was heard in the parliament but came from the Scottish Socialist Party (SSP), prominently headed up by feminist SSP MSPs. Carolyn Leckie was infamously ejected from the Parliament for trying to raise a point of order on the nursery nurse strike while her fellow SSP MSP, Frances Curran, led key debates advocating for the introduction of a national pay settlement for the striking workers. While the SNP would come to support the motion for a national settlement, active campaigning and support came more from the socialist left than mainstream feminism. Perhaps representatively, therefore, the event is not mentioned in Torrance's (2015) biography of Sturgeon. The dispute does not appear to have featured in her political discussion of the time.

Sturgeon symbolises the distinctiveness and contradictions of feminine leadership in devolved Scotland. Her positioning between market imperatives and social justice closely resembles that of Wendy Alexander in the first devolved administration. An emphasis on gender representation and inclusive politics remains, inherited from the devolution campaign and back to the WLM, alongside participation from third sector feminist groups. Yet, these imperatives function within a pro-market framework with its well-recognised gendered impact. Some feminist third sector groups have criticised the Scottish Government's economic policymaking with, for example, the Scottish Women's Budget Group submission on the Covid recovery budget highlighting the need for a caring economy, more non-means tested social security and investment in care among other measures (SWBG Submission 2021). Sturgeon's administration established the Social Justice and Fairness Commission (SJFC 
2020), which claims to build on the government's commitment to both a Wellbeing economy, (WeGo 2020) and the Growth Commission's (2018) prospectus for a liberal market economy in an independent Scotland. The SNP, therefore, views social justice not as a challenge to, but as compatible with, a market-based economy while also claiming to disown the misdirected emphasis on economic growth pursued by earlier administrations. This paradoxical outlook illustrates the limitations of the dominant politics in the devolved parliament which seeks to include women and speak the language of social justice while fostering the system logics that contributed to women's injustices.

\section{Conclusion}

Scotland's experience of feminist politics imbued by a strong commitment to institution building can be understood as a pronounced version of an international trend that has developed across the last four decades in mature and new liberal democracies. While a turn towards transforming national parliaments and parties to improve political parties and gender representation is a common experience, in Scotland these trends have strongly overlapped with the dynamics of nation building and the forging of a new devolved parliament. Feminist campaigning in the run up to devolution was remarkably successful in embedding an unprecedented extent of women's representation within a Scottish context. Even if these levels are less distinctive than they once were at UK level, the idea that, at least some, women's place is in the Parliament seems secured. Perhaps even more significantly, the campaign has also led to a shift in the Scottish cultural imaginary of 'progressive' political leadership in Scotland from militant men to consensus-driven women. These perspectives were consolidated at the 2021 general election when the electorate decisively rejected Alex Salmond's new Alba Party. Alba was positioned as more singularly driven by independence than the SNP under Sturgeon and less imbued with the political culture that the SNP had fortified under devolution. The SNP choosing to form a coalition government with the pro-independence Scottish Green Party following the election, and the elevation of the Greens' co-leader Lorna Slater to the rank of minister further consolidated the assumption that women will continue to play a dominant role in Scottish politics. Slater's association with feminism and social liberalism further underlines these dimensions of consensus building (Wilson 2021).

Despite the high-profile success of female leaders, the 'new politics' of devolution have been less successful in meeting the aspirations of feminists who undertook the institutional turn during the 1980s and 1990s. In 2021, the SNP MSP Aileen Campbell and Labour MSP Jenny Marra both announced they would not stand for re-election due to the difficulty of combining their work in the parliament with family responsibilities. Notably, as highlighted by Marra, their decisions came despite the fact that family friendliness was part of the feminist new politics agenda, 'archaic' Westminster has a full-time nursery while Holyrood lacks one (BBC 2021c). While most equalities legislation has involved a cross-party approach, more generally adversarial rather than consensual politics have been the norm in Holyrood. Moreover, a combative approach is often no more embodied than in the figures 
of Nicola Sturgeon and Ruth Davidson, among the highest profile women of recent parliaments. Sturgeon is often framed in gendered terms as a more consensus-driven leader than her predecessor Salmond, yet she honed her political craft in opposition during FMQs and is well known for her antagonistic approach. The idea of a consensus-driven feminine leadership and parliament is also inherently partial. As an ideal it structures the performance of Scottish feminine leadership. However, the larger aims attached to consensus-building democracy, including cross-party cooperation and especially a more inclusive form of democracy have been more elusive. Limited forms of cross-party cooperation have not transformed the fundamentally adversarial nature of parliamentary politics, especially between the main parties. The most ambitious goal, of a parliament more open to the people, was arguably always at odds with the practices of the SCC and the elite network of feminist activists who put it forward.

However, there remains a question around how consensus is interpreted and whether consensus is always desirable or more 'woman-friendly'. Perhaps, the greatest area of consensus in Scottish political life has emerged in ideological outlook of the SNP and Labour, which dominated the first two decades of the parliament, in spite of their clash on the independence question. Both parties were influenced by the legacies and figures of the WLM and pursued similar equalities agendas. Yet, they also embedded pro-market policies that have furthered the impoverishment of women. These legacies cannot be fully disentangled from one another. While the institutional turn delivered considerable successes for feminists in women's representation, these came at a price. The redress in broader policy terms has been comparatively modest given feminists' egalitarian objectives in the 1980s. These conclusions tend to support existing literature which points to the limitations of achievements in representation alone as well as the latent power of existing national parliamentary cultures in terms of setting the standards of new institutions, which is visible in how Westminster norms influenced Holyrood, despite feminist ambitions for greater difference.

\section{References}

Aitken, K. 1997. The Bairns O' Adam: The story of the STUC. Edinburgh: Polygon.

Ascherson, N. 2003. Stone voices: The search for Scotland. London: Granta.

BBC News. 2021a. Scottish election 2021: Results in maps and charts. https://www.bbc.co.uk/news/ukscotland-scotland-politics-57028315.

BBC News. 2021b. The women who hope to break the mould of Scottish politics. https://www.bbc.co.uk/ news/uk-scotland-56442463.

BBC News. 2021c. MSP mums want Holyrood to be more family friendly. https://www.bbc.co.uk/news/ uk-scotland-scotland-politics-55924054.

BBC News. 2017. Nicola Sturgeon would change SNP name. https://www.bbc.co.uk/news/uk-scotlandscotland-politics-40975105.

Breitenbach, E., and F. Mackay. 2021. Women and contemporary Scottish politics: An anthology. Edinburgh: Edinburgh University Press.

Breitenbach, E. 2006. Developments in gender equality policies in Scotland since devolution. Scottish Affairs 56 (1): 10-21.

Browne, S. 2014. The women's liberation movement in Scotland. Manchester: Manchester University Press. 
Charles, N., and F. Mackay. 2013. Feminist politics and framing contests: Domestic violence policy in Scotland and Wales. Critical Social Policy 33 (4): 593-615.

Commons Library. 2020. General Election 2019: How many women were elected? https://commonslibrary. parliament.uk/general-election-2019-how-many-women-were-elected/.

Dalziel, M. 2018. Hundreds of people flock to Govan Cross as Glasgow's Mary Barbour statue unveiled. Glasgow Live https://www.glasgowlive.co.uk/news/glasgow-news/glasgows-mary-barbour-statue-unvei led-14385125.

Ewing, W. 2004. Stop the world: The autobiography of Winnie Ewing. Michael Russell (eds). Birlinn: Edinburgh

Fyfe, M. 2014. A problem like Maria: A woman's eye view of life as an MP. Luath: Edinburgh.

Gibbs, E. 2016. Historical tradition and community mobilisation: Narratives of Red Clydeside in memories of the anti-poll tax movement in Scotland, 1988-1990. Labor History 57 (4): 439-462.

Gibbs, E., and S. Scothorne. 2020. Accusers of capitalism: Masculinity and populism on the Scottish radical left in the late twentieth century. Social History 45: 218-245.

Galloway, K. and J. Robertson. 1991. Introduction: A woman's claim of right for Scotland'. In Woman's claim of right group, A woman's claim of right in Scotland, 1-6. Polygon: Edinburgh.

Hay, K. 2020. 'More than a defence against bills': feminism and national identity in the Scottish abortion campaign, c. 1975-1990. Women's History Review. https://doi.org/10.1080/09612025.2020.1791405.

Hames, S. 2020. The literary politics of Scottish devolution: Voice, class, nation. Edinburgh: Edinburgh University Press.

Hassan, G. 2019. Back to the future: Exploring twenty years of Scotland's journey, stories and politics. In The story of the Scottish Parliament: The first two decades explained, ed. G. Hassan, 1-27. Edinburgh.

Henderson, S. and A. Mackay (eds.) 1990. Grit and diamonds: Women in Scotland making history, 19801990. Edinburgh: Stramillion.

Hersh, M. 1991. Women in campaigning groups in Central Scotland. In Woman's claim of right group, A woman's claim of right in Scotland, 102-134. Polygon: Edinburgh.

Higgins, M., and F. MacKay. 2016. Gender and the development of a political persona: The case of Scottish first minister Nicola Sturgeon. British Politics 11: 283-300.

Hughes, A. 2010. Gender and political identities in Scotland, 1919-1939. Edinburgh: Edinburgh University Press.

Kane, M. 1990. From inside the council: local government women's committees in the eighties. In Grit and diamonds: Women in Scotland making history, 1980-1990, ed. S. Henderson and A. Mackay, 18-22. Edinburgh: Stramillion.

Kenny, M. 2011. Gender and institutions of political recruitment: Candidate selection in post-devolution Scotland. In Gender, politics and institutions, ed. M.L. Krook and F. Mackay, 21-41. Basingstoke: Palgrave Macmillan.

Kerr, J.B., and P. Jennings. 1990. Scottish feminism in the eighties. In Grit and diamonds: Women in Scotland making history, 1980-1990, ed. S. Henderson and A. Mackay, 45-49. Stramillion: Edinburgh.

Krook, M., and F. Mackay. 2011. Gender, politics and institutions. In Gender, politics and institutions: Towards a feminist institutionalism, ed. M. Krook and F. Mackay, 1-20. London: Palgrave Macmillan.

Law, A., and G. Mooney. 2010. Financialisation and proletarianisation: Changing landscapes of neoliberal Scotland. In Neoliberal Scotland: Class and Society in a Stateless Nation, ed. N. Davidson, 137-159. Newcastle: Cambridge Scholars.

Lindsay, I. 1991. Constitutional change and the gender deficit. In Woman's claim of right group, A woman's claim of right in Scotland, 7-13. Edinburgh: Polygon.

Lynch, M. 2013. SNP: The history of the Scottish National Party. Cardiff: Welsh Academic Press.

Mackay, F. 2011. Conclusion: Towards a feminist institutionalism? In Gender, politics and institutions, ed. M. Krook and F. Mackay. London: Palgrave Macmillan. https://doi.org/10.1057/9780230303911_11.

McCrae, R. 1991. Women in the Scottish Labour Party. In Woman's claim of right group, a woman's claim of right in Scotland, 47-59. Edinburgh: Polygon.

McCullough, K.L. 2018. Resolving the 'Highland Problem': The Highlands and Island of Scotland and the European Union. Local Economy 33 (4): 421-437.

McGarvey, N., and P. Cairney. 2008. Scottish politics: An introduction. London: Palgrave.

McMillan, F. 2020. Devolution, "new politics" and election pledge fulfilment in Scotland, 1999-2011. British Politics 15: 251-269.

Mitchell, J. 2010. The narcissism of small differences: Scotland and Westminster. Parliamentary Affairs 63 (1): 98-116.

Mooney, G., and T. McCafferty. 2005. "Only looking after the weans”? The Scottish nursery nurses' strike, 2004. Critical Social Policy 25 (2): 223-239. https://doi.org/10.1177/0261018305051327. 
Mooney, G., and L. Poole. 2004. "A land of milk and honey"?: Social policy in Scotland after devolution. Critical Social Policy 24 (4): 458-483. https://doi.org/10.1177/0261018304046672.

Nairn, T. 1994, 2001. Gender goes top of the agenda. In Women and contemporary Scottish politics: An anthology, ed. E. Breitenbach and F. Mackay, 195-196. Edinburgh: Edinburgh University Press.

Phillips, J. 2019. Scottish Coal Miners in the twentieth century. Edinburgh: Edinburgh University Press.

Purdie, B., M. Coyne, R. Clark, S. MacPhail, G. Kerevan, T. Nairn, T. Gallacher, I.S. Wood, M. Fyfe, and J.D. Young. 1987. Edinburgh letter: Scotland: A nation challenges Thatcher. Fortnight 255: 15.

Read, J. (2020). 'Nicola Sturgeon, Jacinda Adern and Angela Merkel in top 5 of world's most eloquent leaders'. The New European. https://www.theneweuropean.co.uk/brexit-news/boris-johnson-misses-out-ineloquent-leader-poll-88132

Roddick, J. 1991. Women and politics in Europe. In A woman's clam of right in Scotland: Women, representation and politics, 14-25. Edinburgh: Polygon.

Scotsman. 2017. Nicola Sturgeon explain nippy sweetie nickname. Scotsman. https://www.scotsman.com/ news/politics/nicola-sturgeon-explains-nippy-sweetie-nickname-1442087.

Scottish Executive. 2001. A Smart, successful Scotland: Lessons for the Enterprise Group. https://www. webarchive.org.uk/wayback/archive/3000/https://www.gov.scot/Resource/Doc/158455/0042945.pdf.

Scottish Government. nd 1. Baby boxes. https://www.gov.scot/policies/early-education-and-care/baby-boxes/

Scottish Government. nd 2. Named person. https://www.gov.scot/policies/girfec/named-person/

Scottish Women's Budget Group. 2021. Tackling gender inequalities through the Scottish Budget 2021/22 Parliamentary Briefing. https://www.swbg.org.uk/content/publications/SWBG-Pre-Budget-Parliament ary-Briefing-.pdf.

Shaw, S. 2020. Women, language and politics. Cambridge: Cambridge University Press.

Social Justice and Fairness Commission. 2020. Remit. https://www.socialjustice.scot/.

The Sustainable Growth Commission. 2018. Scotland-the new case for optimism: A strategy for inter-generational economic renaissance. https://static1.squarespace.com/static/5afc0bbbf79392ced8b73dbf/t/ 5b0a988c352f53c0a5132a23/1527421195436/SGC+Full+Report.pdf.

Thiec, A. 2010. Women and politics in post devolution Scotland. Caliban 27: 177-190.

Turok, I. 2007. Urban policy in Scotland: New conventional wisdom, old problems? In Scottish social democracy: Progressive ideas for public policy, ed. M. Keating, 141-168. Brussels: Peter Lang.

Torrance, D. 2013. The Battle for Britain: Scotland and the independence referendum. London: Biteback.

Torrance, D. 2015. Nicola Sturgeon: A political life. Birlinn: Edinburgh.

WeGo. 2020. Nicola Sturgeon: Why governments should prioritise. https://wellbeingeconomy.org/wego

Wilson, L. 2021. Patrick Harvie and Lorna Slater promoted to ministers. Holyrood. https://www.holyrood. $\mathrm{com} /$ news/view,patrick-harvie-and-lorna-slater-promoted-to-ministers

Publisher's Note Springer Nature remains neutral with regard to jurisdictional claims in published maps and institutional affiliations. 